\section{hommes}

\section{Hommes \& migrations}

Revue française de référence sur les dynamiques

migratoires

\section{$1291 \mid 2011$}

Diasporas sri lankaises

\title{
Nous, princesses de Clèves
}

Film français de Régis Sauder

\section{André Videau}

\section{(2) OpenEdition \\ 1 Journals}

Édition électronique

URL : http://journals.openedition.org/hommesmigrations/702

DOI : 10.4000/hommesmigrations.702

ISSN : 2262-3353

Éditeur

Musée national de l'histoire de l'immigration

Édition imprimée

Date de publication : 1 mai 2011

Pagination : 155

ISSN : 1142-852X

\section{Référence électronique}

André Videau, « Nous, princesses de Clèves », Hommes \& migrations [En ligne], 1291 | 2011, mis en ligne le 29 mai 2013, consulté le 22 septembre 2020. URL : http://journals.openedition.org/ hommesmigrations/702; DOl : https://doi.org/10.4000/hommesmigrations.702

Ce document a été généré automatiquement le 22 septembre 2020.

Tous droits réservés 


\title{
Nous, princesses de Clèves
}

\author{
Film français de Régis Sauder
}

\section{André Videau}

1 Réalisateur estimé de nombreux documentaires, Régis Sander s'est efforcé de faire entendre (à l'école, en prison, à l'hôpital...) des voix pas toujours audibles dans le tintamarre médiatique. Avec la complicité de quelques enseignants, il vient de faire le pari risqué de transposer l'univers très codifié et d'un éloignement apparemment galactique de La Princesse de Clèves, premier grand roman inaugural de la littérature française, dans la vie, au jour le jour, d'un groupe d'élèves de première et de terminale du lycée Diderot, établissement réputé difficile et classé en ZEP dans les quartiers nord de Marseille. De la Cour des courtisans sous le règne d'Henri II (1558) décrite par Madame de La Fayette à la cour d'une école publique sous le quinquennat de Sarkozy.

2 On pouvait envisager les risques d'un grand écart, le défi, la provocation, l'égalitarisme utopique, ou mieux encore la réplique à la parole maladroite d'un président soucieux d'épargner les classiques barbants aux classes laborieuses. Mais outre que l'attaque, plus maladroite que drôle, ne coïncidait pas avec le calendrier, il y avait eu plusieurs films où l'école cinématographiée marquait des points, de La Journée de la jupe à Entre les murs en passant par L'Esquive au succès insolent, délicieuse incursion de Marivaux en banlieue où Abdellatif Kechiche piégeait le langage des cités dans les flamboyances et les intermittences du cœur des élites du XvIII ${ }^{\mathrm{e}}$ siècle.

3 Nous, princesses de Clèves est un documentaire, somme toute assez démonstratif. Remarquez ce pluriel qui transgresse les conditions sociales, les sexes ou les origines. Ils furent quarante, puis vingt postulants sélectionnés au cours d'ateliers. On ne leur demandait pas des mimiques et des adaptations autour des transports amoureux de Mademoiselle de Chartres, du prince de Clèves et de leur entourage, mais des affinités avec la noblesse de leurs sentiments, leur exaltation et leur souffrance, les empêchements et les renonciations.

4 Il fallait la faculté de prendre le texte à bras le corps dans une double démarche d'appropriation et d'apprentissage. Le posséder avec respect, puis fierté, puis violence. Le décortiquer en fragments, le lire et le relire, l'apprendre, le jouer. L'adapter à des situations inédites, réconfortantes ou déstabilisantes. Ainsi du voyage initiatique à 
Paris, de la visite à la Bibliothèque nationale avec l'intervention "très pointue" du bibliothécaire. Ainsi de l'univers des parents avec quelques mères courage, sublimes et néanmoins à côté de la plaque. Ainsi de la préparation du bac et des enseignants aux tics ridicules et aux attentions passionnées.

5 Comme on s'est attaché à eux, il faudrait les citer tous : la jeune musulmane qui se demande si, tout compte fait, religion et tradition ne lui ont pas gâché la vie. Telle autre qui assume son passé (révolu) de black gothique. Ou encore ce garçon homosexuel voulant changer de ville pour changer de vie. Le film agit comme un révélateur. Preuves à l'appui, il réhabilite la notion, décriée, de chef-d'œuvre pour tous et éternel. On ne peut que l'en féliciter. 